\title{
A Faculdade de Ciências do Desporto e de Educação Física da Universidade do Porto e a prestação de serviços - que política?
}

\author{
Fernando Tavares \\ Vice-Presidente do Conselho Directivo da Faculdade de Ciências \\ do Desporto e de Educação Física da Universidade do Porto
}

https://doi.org/10.5628/rpcd.01.01.44

\section{INTRODUÇÃO}

A plena integração da Faculdade no seio da Universidade do Porto, assinala uma mudança, não só da passagem do ensino médio para o ensino universitário, como também uma mudança de atitude em relação ao relacionamento com o exterior. Assumido e estabilizado que estava o reconhecimento interno da qualidade da formação ministrada tornou-se evidente que a partir desse momento haveria que alargar horizontes.

A Faculdade para além da "produção" de conhecimentos e de diplomas, deve prestar a atenção necessária e suficiente àqueles que são ou poderão constituir-se em seus "clientes": estudantes, exalunos, sociedade em geral, etc. É neste contexto, que se desenvolve a missão da Faculdade, onde o Desporto possui uma dimensão em toda a sua actividade que permite a sua extensão à comunidade de forma distinta e segundo as suas capacidades. A este respeito, os estatutos definem como objecto de estudo o Desporto e este numa perspectiva abrangente e plural. Ou seja, enquanto prática diferenciada nos domínios da educação e formação institucionais, do rendimento desportivo, da recreação e tempos livres, da reeducação e reabilitação. O nosso plano de estudos, modelado por padrões europeus, define claramente o campo de intervenção.

\section{PRESENÇA NO MEIO}

Conferindo ao desporto uma importância efectiva na formação e na investigação, a relação com o meio deve ser considerada com toda a relevância. Ela, pode ser reforçada através da visibilidade das suas iniciativas e da influência pública que pode ser exercida através da divulgação e utilização pública do que faz e produz em matéria de ensino, de investigação, prestação de serviços e através da participação institucional no espaço público e nos grandes projectos mobilizadores da cidade. É um facto que hoje a Faculdade não consegue dar resposta a todas as solicitações, constituindo-se estas numa prova do reconhecimento e vitalidade da mesma. Contudo a prestação de serviços não pode ser desinserida da ideia de qual a missão primeira da Faculdade. Isto significa, que esta pode prestar serviços à comunidade, mas não pode esquecer que, antes de mais, é uma instituição de Formação. A presença no meio obriga, também, da parte da instituição a uma clara definição da sua relação com ele, no princípio do respeito pela diversidade dos parceiros sociais considerados fundamentais ou prioritários para a Faculdade. Assim, esta deverá saber escolher no momento e em função das suas necessidades quais os parceiros que melhor se posicionam para dar resposta aos seus objectivos. Estão neste caso, os clubes desportivos, as associações e federações desportivas, as autarquias, as empresas e as organizações não lucrativas. Para com todos eles devemos cultivar uma atitude de comunicação e cooperação em que as vantagens sejam mútuas. De igual modo, as formas de relacionamento deverão ser diversificadas, não devendo esquecer a utilidade material da prestação de serviços. Este tem sido um princípio levado a cabo pela Faculdade e do qual tem resultado, em função do interesse manifestado e desenvolvido através das actividades dos gabinetes e laboratórios, a prestação de alguns serviços à comunidade. Podemos citar neste caso, a elaboração e aplicação de programas de 
actividades físicas e desportivas para pessoas da terceira idade e para crianças; apoio a populações com cuidados especiais, etc.

\section{RELAÇÃO COM O SISTEMA DESPORTIVO}

Pela sua vocação e opção estratégica a instituição tem procurado alguma articulação com o Sistema Desportivo e dentro das suas actividades de extensão o relacionamento com este tem sido objecto de interesse crescente.

Tem permitido formar parcerias importantes, mais pelo acolhimento dos seus estudantes e até do prestígio da própria instituição, do que do ponto de vista do financiamento à Faculdade. Estas parcerias e protocolos assinados com as Federações Desportivas e outras Instituições têm permitido aos nossos estudantes exerceram a sua actividade enquanto "estagiários" e simultaneamente serem os transmissores do "saber adquirido", tornando-se uma mais valia no prestígio da instituição no exterior. Os vários protocolos firmados pela Faculdade com associações e federações desportivas nos últimos anos, são prova evidente do desenvolvimento da actividade de prestação de serviços com vantagens mútuas e que se identificam fundamentalmente nos domínios da formação, da investigação e de consultadoria. Em relação a estes domínios têm sido considerados os seguintes aspectos:

- a formação de quadros técnicos;

- realização de estudos no domínio da definição das condições de optimização do rendimento desportivo;

- apoio ao trabalho das selecções nacionais, no que diz respeito ao desenvolvimento de programas e exames específicos;

- serviços de consultadoria em assuntos referentes às respectivas modalidades desportivas.

\section{FUTURO}

Quanto ao futuro a Faculdade deverá continuar a investir no estabelecimento conjunto de cooperações e parcerias com instituições que permitam alargar e consolidar cada vez mais o seu campo de intervenção.

Se quisermos manter e até desenvolver a relação com o exterior e acompanhar as transformações que aí se verificam, teremos de ser capazes de avaliar com mais frequência "a satisfação dos nossos clientes”. Esta confrontação com o exterior, colocanos na posição de que, o que nos chega ou existe no exterior, não pode ser ignorado, mas antes questionado e ouvido de modo a podermos dar as respostas e encontrar as soluções que o meio exige. Do modo como as instituições de ensino superior encararem a elevação do nível da qualidade da sua formação dependerá o seu futuro. Por isso não basta que assistam à configuração do mundo pelo mercado e que prestem serviços nesse sentido. Ou seja, há que apostar numa cultura de qualidade que se traduza em criar uma perseverança de intenções/deliberações para procurar sempre uma melhoria dos produtos e dos serviços. De uma maneira geral, pode-se dizer que a preocupação de se voltar também para o grau de satisfação dos clientes (estudantes, sistema desportivo, escola e sociedade em geral) fundamentase também no princípio de que uma organização deve ter uma gestão focalizada na qualidade dos serviços, dos produtos e das pessoas. 